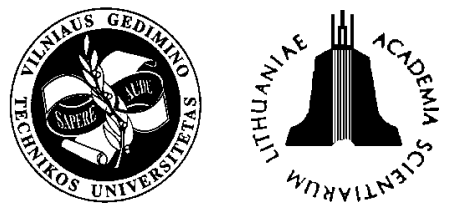

ISSN 1648-4142 print / ISSN 1648-3480 online TRANSPORT

www.transport.vtu.lt

TRANSPORT - 2006, Vol XXI, No 3, 189-196

\title{
CLASSIFICATION AND CODING: APPROACH OF DIFFERENT INTERNATIONAL ORGANIZATIONS
}

\author{
Ülo Hunt ${ }^{1}$, Ott Koppel ${ }^{2}$ \\ ${ }^{1}$ Estonian Railways Ltd, 36 Pikk Street, 15073 Tallinn, Estonia.E-mail: hunteree@yahoo.com \\ ${ }^{2}$ Dept of Transportation at Tallinn University of Technology, 5 Ehitajate Street, \\ 19086 Tallinn, Estonia.E-mail: okoppel@hot.ee
}

Received 8 January 2006, accepted 9 May 2006

\begin{abstract}
Transportation plays a significant role in the world. This paper deals with harmonization of classification and coding systems, which is of fundamental importance in everyday freight handling practice.
\end{abstract}

Keywords: railroad, harmonization, nomenclature, classification, coding, model.

\section{Introduction}

The European and Asian railway companies are joined into two international railway organizations - UIC and OSJD. In order to harmonize the tariff policy and freight statistics, these organizations have agreed to use a common nomenclature of goods. In UIC this list of goods is known as NHM and in OSJD as GNG.

It seems that the administration of this list is the easiest thing to do. Nevertheless, even such big organisations may get confused while dealing with such a simple thing and waste a lot of time, energy and labour to administer, coordinate and synchronise the list.

First, let us recall the basics of classification and encoding, and later we will be looking at the practical activities related both in time and space.

\section{Literature review, method and data}

\subsection{Classification and coding of the information}

The important concept at work with the information is classification of objects [1-7].

Classification is a method of distribution of objects (subjects, the phenomena, processes, concepts) to classes according to the certain attribute.

The object is understood as any subject, process, the phenomenon of material or non-material property. The system of classification allows to group objects and to allocate to the certain classes which will be characterized by a number of the common properties.
Classification of objects is a procedure of grouping at the qualitative level, directed to allocation of homogeneous properties.

With reference to the information as to object of classification the allocated classes are named as information objects.

Properties of information object are defined by the information parameters named essential elements.

Essential elements are represented as the numerical data, for example, weight, cost, year, or attributes, and for example, color, mark of the machine, a surname.

The essential element is a logically indivisible information element describing certain property of object, process, the phenomenon, etc.

Except for revealing the common properties of information object classification is necessary for the development of rules (algorithms) and procedures of processing of the information submitted by set of essential elements.

The algorithm of processing of information objects of library fund allows to receive the information on all books on the certain subjects, about authors, subscribers, etc.

The algorithm of processing of information objects of firm allows to receive the information on sales volumes, on the profit, customers, kinds of made production, etc.

Algorithms of processing in that and other cases pursue the different purposes, process the different information, and are realized by different ways. 
At any classification it is desirable, that the following requirements were observed:

- Completeness of scope of objects of considered area;

- Unambiguity of essential elements;

- An opportunity of inclusion of new objects.

The qualifier is the systematized arch of names and codes of classification groupings.

At classification concepts a classification attribute and the value of a classification attribute which allow to establish similarity or distinction of objects are widely used. The approach to classification with association of these two concepts in one, is named as an attribute of classification. The attribute of classification also has a synonym, i. e. the basis of division.

Three methods of classification of objects are developed:

- Hierarchical (to this method we accent our paper below);

- Facet (Facet is a group of headings which all define a certain method of classification. That is, a facet is a way in which a resource can be classified; for example, classified by color, classified by geography, classified by subject, etc. In a strict faceted classification model, a resource is classified under one heading from each facet that applies to it. A resource does not have to be classified at all in a given facet, if that facet's method of classification doesn't apply to the resource);

- Descriptor (descriptor system is a semi-hierarchical system with several descriptors for describing the state of goods and other objects of nature; descriptor subsets should be selected for the study goals. The role of a descriptor is to further describe the use of the keyword, and each keyword entry has a list of the approved descriptors to be used with that term).

These methods differ in different strategy of application of classification attributes. We shall consider the basic ideas of these methods for creation of hierarchical systems of classification.

\subsection{Hierarchical system of classification}

The hierarchical system of classification (Fig) is created by the following method:

- The initial set of elements makes 0-level and shares depending on the chosen classification attribute on classes (groupings) which form the $1^{\text {st }}$ level;

- Each class of the $1^{\text {st }}$ level according to a classification attribute shares on subclasses which form the $2^{\text {nd }}$ level;

- Each class of the $2^{\text {nd }}$ level similarly shares on groups which form the $3^{\text {rd }}$ level, etc.

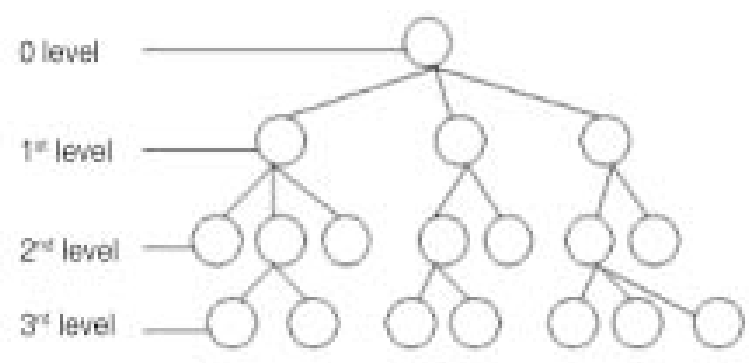

Hierarchical system of classification

Taking into account rigid enough procedure of the construction of structure of classification, it is necessary to determine its purpose before the beginning of work, i.e. what properties objects united in classes should possess. These properties are accepted further for attributes of classification.

Remember - in hierarchical system of classification the special attention should be given to a choice of classification attributes.

In hierarchical system of classification each object at any level should be related to one class which is characterized by concrete value of the chosen classification attribute. On the day of the subsequent grouping of each new class it is necessary to set the classification attributes and their values. Thus, the choice of classification attributes will depend on the semantic contents of that class for which the grouping at the subsequent level of hierarchy is necessary.

The amount of levels of the classification, corresponding to number of the attributes chosen as the basis of division, characterizes the depth of classification.

Advantages of hierarchical system of classification:

- Simplicity of construction;

- Use of independent classification attributes in various branches of hierarchical structure.

Lacks of hierarchical system of classification:

- Rigid structure which leads to the complexity of modification as it is necessary to redistribute all classification groupings;

- Impossibility to group objects on beforehand not stipulated combinations of attributes.

\subsection{System of Coding}

Common concepts:

- The system of coding is applied to replacement of the name of object by a symbol (code) with a view to maintain the convenient and more effective processing of the information;

- System of coding is the set of rules of a code designation of objects. 
The code is constructed on the basis of the alphabet consisting of letters, figures and other symbols. The code is characterized by:

- The length - number of positions in a code;

- Structure - the order of an arrangement in a code of the symbols used for a designation of a classification attribute.

Procedure of assignment to object of a code designation refers to as coding. It is possible to allocate two groups of the methods used in system coding form:

- The classification system of coding focused on carrying out the preliminary classification of objects either on the basis of hierarchical system or on the basis of facet systems;

- The registration system of coding which is not demanding preliminary classification of objects.

\subsection{Classification coding}

Classification coding is applied after carrying out classification of objects. Consecutive and parallel coding systems are distinguished.

Consecutive coding is used for hierarchical classification structure. The essence of the method consists in the following: the code of the senior grouping of the $1^{\text {st }}$ level, then a code of a grouping of the $2^{\text {nd }}$ level, then a code of a grouping of the $3^{\text {rd }}$ level, etc., first enters the name. As a result, the code combination where each category contains the information on specificity of the allocated group at each level of hierarchical structure turns out. The consecutive system of coding possesses the same merits and demerits as the hierarchical system of classification.

\subsection{Registration coding}

Registration coding is used for unequivocal identification of objects and does not demand preliminary classification of objects. Serial and serial serial systems are distinguished.

The serial system of coding assumes consecutive numeration of objects by numbers of natural lines. This order can be casual or be determined after preliminary ordering objects, for example alphabetically. This method is applied in that case when the quantity (amount) of objects is insignificant, for example, coding of names of faculties of university, coding of students in educational group.

The serial - serial system of coding provides preliminary allocation of groups of objects that make a series, and then in each series the serial numbering of objects is made. Each series will also have serial numbering. Inherently the serial - serial system is mixed: classifying and identifying. It is applied when the amount of groups is insignificant.

\section{Basics of different goods classification systems}

\subsection{Harmonized Commodity Coding System (HS)}

The Harmonized Commodity Description and Coding System (HS) is a classification system for goods entering an importing country through Customs. Its 97 Chapters can be used to classify every commodity traded among countries. Periodically, the Customs Cooperation Council recommends revisions to the HS system to reflect changes in technology or patterns of trade.

Almost 190 countries and territories, representing about $98 \%$ of world trade, use the HS as a basis for:

- Customs tariffs;

- Collection of international trade statistics;

- Rules of origin;

- Collection of internal taxes;

- Trade negotiations (e.g., the World Trade Organization schedules of tariff concessions);

- Transport tariffs and statistics;

- Monitoring of controlled goods (e.g., wastes, narcotics, chemical weapons, ozone layer depleting substances, endangered species);

- Areas of Customs controls and procedures, including risk assessment, information technology and compliance.

The HS is intended to serve as a universally accepted classification system for goods, so countries can administer customs programs and collect trade data on exports and imports. It was designed to replace the local systems used by countries allowing them to have a common classification system by which to track trade and apply tariffs.

The basic system uses a 6-digit number to identify basic commodities. Each country is allowed to add additional digits for statistical purposes. In Canada additional 2-digits are used for exports and additional 4-digits for imports. The U.S. uses a 10-digit system for both exports and imports.

HS was developed under the auspices of the Customs Cooperation Council (CCC), at present known as the World Customs Organization (WCO). The WCO, located in Brussels is an international organization consisting of representatives of about 139 countries or territories.

The Nomenclature governed by the Convention on the Harmonized Commodity Description and Coding System, commonly known as "HS Nomenclature", is an international multipurpose nomenclature that was elaborated under the auspices of the World Customs Organization (WCO). At present there are 116 Contracting Parties to this Convention, however, it is applied by more than 190 administrations worldwide, mostly to set up their national customs tariff and for the collection of economic statistical data. The 
European Union and its member states together represent a block of 26 Contracting Parties to the aforementioned Convention.

The HS Nomenclature comprises about 5,000 commodity groups that are identified by a 6 -digit code and arranged according to a legal and logical structure based on fixed rules.

The official interpretation of the HS that provides for its uniform interpretation worldwide is ensured by the HS Committee that comprises representatives from the Contracting Parties to the HS Convention. Other administrations, international organizations, international commerce and industry are represented as observers.

The HS Convention provides for two types of decisions taken by the HS Committee:

1. Decisions which amend the Convention including its nomenclature, and

2. Decisions which "manage or interpret" the Convention and which normally take the form of classification decisions, Explanatory Notes or Classification opinions

In both cases, the EC and its member states, together, dispose of a single vote only. The Contracting Parties may lodge a "reservation" against both types of decisions. A "reservation" against an amendment of the Convention annuls the decision that was taken. On the other hand, the legal effect of a "reservation" in the framework of the Convention is limited to a suspension of the decision which has to be re-examined at a later meeting of the Committee. In practice, this simply means that the definitive decision is delayed by 6 to 12 months.

Generally, the amendments to the HS Convention become binding for all Contracting Parties two years after they are notified by the Secretary General of the WCO. However, the decisions concerning the management and interpretation of the Convention are generally deemed to have been accepted by all Contracting Parties two months after the decision by the HS Committee.

\subsection{History of amendments of HS}

The Harmonized System is amended every five years. The first amendment occurred in 1992 and consisted mainly of editorial amendments.

The second amendment came into force on 1 January 1996. It incorporated substantial changes affecting about ten percent of the nomenclature.

The third recommended amendments came into force on 1 January 2002.

The fourth recommended amendments will be implemented on 1 January 2007.

\subsection{Structure of the classification}

The HS has a 6-digit structure reflecting commodities that are significant in world trade. An example of the HS structure is given below.

The hierarchical arrangement of the HS categories is as follows:

- 21 Sections;

- 98 Chapters at the 2-digit level;

- 1,244 Headings at the 4-digit level;

- 5,224 Subheadings at the 6-digit level.

Structure of original HS Code:

- Harmonized System begins with Sections. Harmonized Commodity Description \& Coding System is divided into 21 sections as below (Table 1).

- Each section consists of several Chapters.

- Each chapter is denoted by a 2-digit code that is further divided into several 4-digit codes.

- These headings are subdivided into 6-digit codes (HS sub-headings).

- The Chapter 77 is kept reserved by WCO.

- Two additional chapters 98 and 99 are marked for special use by contracting parties.

- HS Codes at 6-digit levels are further sub-divided into 8-digit level to suit the national requirements.

Table 1. Sections of Harmonized Commodity Description \& Coding System

\begin{tabular}{|c|c|c|}
\hline Section & Short name & $\begin{array}{c}\text { HS } 2 \text { eldest digits } \\
\text { (Chapter) }\end{array}$ \\
\hline Section I & animal products & 01 \\
\hline Section II & vegetable products & 06 \\
\hline Section III & edible oils & 15 \\
\hline Section IV & prepared foodstuffs & 16 \\
\hline Section V & mineral products & 25 \\
\hline Section VI & chemical products & 28 \\
\hline Section VII & plastics & 39 \\
\hline Section VIII & fur and skins & 41 \\
\hline Section IX & wood products & 44 \\
\hline Section X & cellulose products & 47 \\
\hline Section XI & textiles & 50 \\
\hline Section XII & misc/manufactures & 64 \\
\hline Section XIII & stone \& ceramics & 68 \\
\hline Section XIV & semi-precious & 71 \\
\hline Section XV & base metals & 72 \\
\hline Section XVI & machinery/mech. & 84 \\
\hline Section XVII & vehicles & 86 \\
\hline Section XVIII & precision & 90 \\
\hline Section XIX & arms/ammunitions & 93 \\
\hline Section XX & beds/bedding & 94 \\
\hline Section XXI & art/antiques & 97 \\
\hline- & industrial plant & 98 \\
\hline- & free for internal use & 99 \\
\hline
\end{tabular}




\subsection{How the HS works}

The Harmonized System is a commodity classification system in which articles are grouped largely according to the nature of the materials of which they are made, as has been traditional in customs nomenclatures.

The Harmonized Commodity Description and Coding System is a 6-digit multipurpose nomenclature for transportable goods, which meets simultaneously the needs of Customs authorities, statisticians concerned with external trade or production, carriers and producers. The Harmonized System is suitable for automatic data processing and transmission which provides a common terminology and code specifically identifying 5,224 groups of goods resulting from a detailed expansion of 1,244 4-digit headings. The latter results from a very extensive revision and updating, not only in detail but also in structure, of the Customs Cooperation Council Nomenclature (CCCN). The Harmonized System can be further subdivided, where necessary, to meet national or international requirements.

The HS provides a logical structure within which 1,244 headings are grouped in 98 Chapters, the latter being arranged in 21 Sections. Each heading is identified by a 4-digit code, the first two digits of which indicate the Chapter wherein the heading appears, while the latter two indicate the position of the heading in the Chapter. Thus, heading 10.01 ("wheat and meslin") is the first heading of Chapter 10, which, in its entirety, covers "cereals".

In addition, most of the headings are subdivided into two or more 1-dash subheadings which, where necessary, are further subdivided into two or more 2-dash subheadings and which are identified by a 6-digit code (HS code):

- Where the description of an article or a group of articles under a heading is preceded by “-”, the said article or group of articles shall be taken to be a sub classification of the article or the group covered by the heading. Where, however the description of an article or group of articles is preceded by “- -", the said article or group of articles shall be taken to be a sub classification of the immediately preceding description of the article or group of articles which has "-".

- Where the description of an article or group of articles is preceded by ". . .", the said article or group of articles shall be taken to be a subclassification of the immediately preceding Harmonized System Code.

The HS comprises 5,224 separate groups of goods identified by a 6 -digit code, the first four digits thereof correspond to the relevant heading number, while the fifth and sixth digits identify the 1- and 2-dash subheadings respectively. The absence of such subheadings is indicated to be a zero.

For example ${ }^{1}$ see Table 2.

In principle, headings and subheadings are numbered in a consecutive way. This principle is, however, interrupted as from 1996, due to the fact that HS codes should be amended when its content is changed.

Table 2. Example of goods coding by a 6-digit code

\begin{tabular}{|c|c|c|}
\hline Heading & $\begin{array}{l}\text { H.S. } \\
\text { Code }\end{array}$ & Description \\
\hline 08.02 & & $\begin{array}{l}\text { Other nuts, fresh or dried, whether } \\
\text { or not shelled or peeled. }\end{array}$ \\
\hline & & - Almonds: \\
\hline & 0802.11 & - In shell \\
\hline & 0802.12 & - Shelled \\
\hline & & $\begin{array}{l}\text { - Hazelnuts or filberts } \\
\text { (Corylus spp.): }\end{array}$ \\
\hline & 0802.21 & - In shell \\
\hline & 0802.22 & - Shelled \\
\hline & & - Walnuts: \\
\hline & 0802.31 & - In shell \\
\hline & 0802.32 & - Shelled \\
\hline & 0802.40 & - Chestnuts (Castanea spp.) \\
\hline & 0802.50 & - Pistachios \\
\hline & 0802.90 & - Other \\
\hline 08.03 & 0803.00 & $\begin{array}{l}\text { Bananas, including plantains, fresh } \\
\text { or dried }\end{array}$ \\
\hline 08.04 & & $\begin{array}{l}\text { Dates, figs, pineapples, avocados, } \\
\text { guavas, mangoes and mango-steens, } \\
\text { fresh or dried }\end{array}$ \\
\hline & 0804.10 & - Dates \\
\hline & 0804.20 & - Figs \\
\hline & 0804.30 & - Pineapples \\
\hline \multicolumn{3}{|l|}{ Notes: } \\
\hline (i) & \multicolumn{2}{|c|}{$\begin{array}{l}\text { HS code } 0803.00 \text { means: the third heading of } \\
\text { Chapter } 8 \text {, which has not been subdivided; }\end{array}$} \\
\hline (ii) & \multicolumn{2}{|c|}{$\begin{array}{l}\text { HS code } 0804.10 \text { means: the first heading of } \\
\text { Chapter } 8 \text {, first subheading which has not been } \\
\text { further subdivided; }\end{array}$} \\
\hline (ii) & \multicolumn{2}{|c|}{$\begin{array}{l}\text { HS code } 0802.21 \text { means: the third heading of } \\
\text { Chapter } 8 \text {, first } 2 \text {-dash subheading of the second } \\
\text { 1-dash subheading. }\end{array}$} \\
\hline
\end{tabular}

1 Source: www.wcoomd.org/ie/En/Topics_Issues/ HarmonizedSystem/DocumentDB/0208E.pdf 
The HS classification is uniform for all countries only through the first 6 digits. Any country may choose to further break down the 6-digit classification to describe a product more specifically. Eight digits is generally considered to be fully qualified for Customs purposes, but some countries may require a $9^{\text {th }}, 10^{\text {th }}$ or further digits to completely describe the specific good being imported.

But the same 8-digit class can represent different products in different countries. For example, 2001.90.30 means "beans" in the US classification and "sweet corn" in the EU-25 classification.

To find a concordance between the HS classification for your product in the US and its classification in the EU-25, start at the 6-digit level and read the descriptions to find the one which describes your product best.

\subsection{The Combined Nomenclature (CN)}

When declared to customs in the Community, goods must generally be classified according to the Combined nomenclature or $\mathrm{CN}$. Imported and exported goods have to be declared stating under which subheading of the nomenclature they fall. This determines which rate of customs duty is applied and how the goods are treated for statistical purposes.

The $\mathrm{CN}$ is a method for designating goods and merchandise that was established to meet, at one and the same time, the requirements both of the Common Customs Tariff and of the external trade statistics of the Community. The $\mathrm{CN}$ is also used in intra-Community trade statistics.

The $\mathrm{CN}$ is comprised of the Harmonized System (HS) nomenclature with further Community subdivisions. HS is run by the World Customs Organization (WCO). This systematic list of commodities forms the basis for international trade negotiations, and is applied by most trading nations. The $\mathrm{CN}$ also includes preliminary provisions, additional section or chapter notes and footnotes relating to $\mathrm{CN}$ subdivisions. Each $\mathrm{CN}$ subdivision has an 8-digit code number, the $\mathrm{CN}$ code, followed by a description.

The basic regulation is Council Regulation (EEC) No 2658/87 on the tariff and statistical nomenclature and on the Common Customs Tariff. An updated version of the Annex I to the Combined Nomenclature Regulation is published as a Commission Regulation every year in the L-series of the Official Journal of the European Communities (as well as on CD-ROM). Such updates take into account any changes that have been agreed at international level, either at the World Customs Organization with regard to the nomenclature at HS level or within the framework of the WTO with regard to conventional rates of duty. Other changes may be required to reflect the evolution of commercial policy, technology or statistical requirements.

\subsection{History of amendments of $\mathrm{CN}$}

The main legal basis of $\mathrm{CN}$ is the document "Council of the European Communities, Regulation No 2658/87, of 23 July 1987, on the tariff and statistical nomenclature and on the Common Customs Tariff(Basic regulation) (Official Journal of the European Communities No L 256, 07.09.1987)".

EU publishes amendments every year in October (last amendments: Commission regulation (EC) No 1719/2005 of 27 October 2005 amending Annex I to Council Regulation (EEC) No 2658/87 on the tariff and statistical nomenclature and on the Common Customs Tariff).

In December Statistical Office of the European Communities re-order the mentioned material for common use by information handling systems and publish files in his web-site (http://europa.eu.int).

\subsection{Structure of the classification of $\mathrm{CN}$}

Structure of the classification of $\mathrm{CN}$ is presented in Table 3.

The Combined Nomenclature $(\mathrm{CN})$ had several changes every year (see Table 4).

Table 3. Structure of the classification of $\mathrm{CN}$

\begin{tabular}{|l|l|}
\hline Sections & $\begin{array}{l}\text { Codes in roman } \\
\text { digits }\end{array}$ \\
\hline Chapters & HS2 Codes: i.e. 22 \\
\hline Sub-chapters & $\begin{array}{l}\text { Codes in roman } \\
\text { digits }\end{array}$ \\
\hline HS headings: & HS4 codes: i.e. 2204 \\
\hline $\begin{array}{l}\text { Non-codified intermediate lines } \\
\text { (between levels HS4 and HS6): }\end{array}$ & No codification \\
\hline HS subheadings & $\begin{array}{l}\text { HS6 codes: i.e. } \\
\text { 2204 21 }\end{array}$ \\
\hline $\begin{array}{l}\text { Non codified intermediate lines } \\
\text { (between levels HS6 and CN8) }\end{array}$ & No codification \\
\hline CN subheadings & $\begin{array}{l}\text { CN codes: i.e. } \\
22042142\end{array}$ \\
\hline
\end{tabular}

Table 4. Combined Nomenclature's $(\mathrm{CN})$ several changes by years

\begin{tabular}{|l|c|c|c|}
\hline \multicolumn{1}{|c|}{ Count of CN } & 2004 & 2005 & 2006 \\
\hline Sections & 21 & 21 & 21 \\
\hline Chapters (2-digit) & 98 & 98 & 98 \\
\hline Headings (4-digit) & 1,244 & 1,244 & 1,244 \\
\hline Sub-headings (6-digit) & 5,224 & 5,224 & 5,224 \\
\hline $\begin{array}{l}\text { Statistical Keys } \\
\text { (8-digit) }\end{array}$ & 10,174 & 10,096 & 9,842 \\
\hline Grand Total & 16,761 & 16,683 & 16,429 \\
\hline
\end{tabular}




\section{Different railroad practices}

\subsection{International Union of Railways (UIC) and history of amendments of NHM}

One important function of UIC is handling of nomenclature of goods (see Table 5).

- January 1976 - Premiere edition published under the title: "Common Nomenclature of the goods (CIM)".

- January 1986 - New title: "Common Nomenclature of goods (NCM)".

- January 1994 - The title: "Harmonized Nomenclature of goods (NHM)".

- Year 2002 - Introducing NHM based on HS-2002. The biggest mistake of NHM creators was assigning code values to "dashed" descriptor fields of HS and $\mathrm{CN}$.

- June 2004 - Recasting of the NHM.

- 19.04.2005 - UIC introduced repaired version of NHM based on CN (2004) on his website.

Table 5. Specific railway codes in NHM

\begin{tabular}{|c|c|}
\hline 27210000 & White spirit \\
\hline 27220000 & Special spirits, n.o.s. \\
\hline 27230000 & Aviation spirit \\
\hline 27240000 & $\begin{array}{l}\text { Motor spirit, lead free (maximum } 0.013 \mathrm{~g} \text { per } \\
\text { litre) }\end{array}$ \\
\hline 27250000 & $\begin{array}{l}\text { Motor spirit, leaded (more than } 0 . .013 \mathrm{~g} \text { per } \\
\text { litre) }\end{array}$ \\
\hline 27260000 & Spirit type jet fuel, light \\
\hline 27290000 & $\begin{array}{l}\text { Light oils, from petroleum or bituminous } \\
\text { materials, n.o.s. }\end{array}$ \\
\hline 27310000 & Medium oils, type jet fuel \\
\hline 27320000 & Kerosine (other than jet fuel) \\
\hline 27390000 & $\begin{array}{l}\text { Medium oils, from petroleum or bituminous } \\
\text { materials, n.o.s. }\end{array}$ \\
\hline 27410000 & Diesel fuel \\
\hline 27420000 & Gas oils, n.o.s. \\
\hline 27430000 & Light fuel oils \\
\hline 27440000 & Heavy fuel oils \\
\hline 27450000 & Lubricating oils, used \\
\hline 27460000 & Lubricating oils, unused \\
\hline 27490000 & $\begin{array}{l}\text { Heavy oils, from petroleum or bituminous } \\
\text { materials, n.o.s. }\end{array}$ \\
\hline 99010000 & Furniture removal equipment \\
\hline 99020000 & Groupage freight \\
\hline 99030000 & $\begin{array}{l}\text { Consignment being conveyed using services } \\
\text { purchased from another RU }\end{array}$ \\
\hline 99110000 & Mortal remains \\
\hline 99210000 & $\begin{array}{l}\text { Privately owned 2-axled wagon, empty, } \\
\text { prior to or after having been used for a } \\
\text { loaded journey under the conditions of a } \\
\text { tariff in which the RU participates }\end{array}$ \\
\hline
\end{tabular}

\begin{tabular}{|c|c|}
\hline 99220000 & $\begin{array}{l}\text { Privately owned wagon with more than two } \\
\text { axles, empty, prior to or after having been } \\
\text { used for a loaded journey under the } \\
\text { conditions of a tariff in which the RU } \\
\text { participates, n.o.s. }\end{array}$ \\
\hline 99230000 & $\begin{array}{l}\text { Transport frames for horizontal transhipment } \\
\text { (for example ACTS, Multiberces, etc), } \\
\text { empty, used before or after transport by rail } \\
\text { with payload }\end{array}$ \\
\hline 9924 & $\begin{array}{l}\text { Privately owned 2-axled wagon, empty, } \\
\text { prior to or after having been used for a } \\
\text { loaded journey under the conditions of a } \\
\text { tariff in which the RU does not participate }\end{array}$ \\
\hline 992 & $\begin{array}{l}\text { Privately owned wagon with more than } 2 \\
\text { axles, empty, prior to or after having been } \\
\text { used for a loaded journey under the } \\
\text { conditions of a tariff in which the RU does } \\
\text { not participate, n.o.s. }\end{array}$ \\
\hline 992 & $\begin{array}{l}\text { Empty wagon with two axles, being } \\
\text { conveyed prior to or after revision or } \\
\text { cleaning }\end{array}$ \\
\hline 9927 & $\begin{array}{l}\text { Empty wagon with more than two axles, } \\
\text { being conveyed prior to or after revision or } \\
\text { cleaning }\end{array}$ \\
\hline 993 & $\begin{array}{l}\text { ers, large, empty, used, before or } \\
\text { nsport by rail with payload }\end{array}$ \\
\hline 99320000 & $\begin{array}{l}\text { Swap bodies, empty, } \\
\text { transport by rail with pa }\end{array}$ \\
\hline 993 & 1, before or after \\
\hline 99 & $\begin{array}{l}\text { Road vehicles of the "rolling road" system, } \\
\text { empty, used, before or after transport by rail } \\
\text { with payload }\end{array}$ \\
\hline 993 & - \\
\hline 993 & $\begin{array}{l}\text { Intermodal transport units, empty, used, } \\
\text { before or after transport by rail with payload, } \\
\text { n.o.s. }\end{array}$ \\
\hline 99410 & Containers, large, loaded \\
\hline 99420000 & Swa \\
\hline 9943 & Semi-trailers, loaded \\
\hline 99 & $\begin{array}{l}\text { Road vehicles of the "rolling road" system, } \\
\text { loaded }\end{array}$ \\
\hline 99490000 & insport units, loaded, n.o.s. \\
\hline
\end{tabular}

4.2. Organization for the collaboration of the railroads (OSJD)

Among other functions OSJD handle GNG (Russian abbreviation of harmonized nomenclature of goods). Harmonized nomenclature of goods (GNG) is obligatory in use on all OSJD railways. GNG is created according to the requirements of World Custom Organization and is corresponding to UIC NHM 2003 edition. Amendments into GNG step into force after approving by OSJD Railway General Directors Conference.

OSJD railways have started using overall GNG since 01.10.2004. The new actual GNG (2004) version was created on the basis of UIC NHM version of 01.01.2003. 
Structure of GNG with sections, chapters, headings and sub-headings is corresponding with HS. Statistical keys and special railway codes correspond with NHM.

Official version of GNG consists of 22 sections and 99 chapters and is divided into analytical and alphabetical name lists. GNG is issued in the Russian language.

\section{Conclusions}

A good nomenclature of goods should ensure:

1. That every product manufactured or otherwise, gets covered under a code number uniformly applied the world over;

2. That a set of rules is available for interpretation;

3 . That the nomenclature is accepted internationally as a technical and legal basis for improving trade relations amongst countries;

4. That a statistical base, suitable for computerization is available.

It is clear, that requirements of classification and coding described in chapter 2 of this paper are not used in every-day practice. Above all, requisitions of hierarchical system of classification must come into use. It is a demand of computer systems and new technologies, especially using XML language.

The process of classification of goods is of paramount importance now, as both industrialized and developing countries as well as several international organizations use it as a tool for implementation of various trade policy instruments, international commercial arrangements, multilateral Tariff agreements. Further, as the variety of products traded internationally grows rapidly, it is all the more necessary that the nomenclature keeps up with the technological progress.

\section{References}

1. Classification and coding of information. Informatics: Textbook (Классификация и кодирование информации. Информатика: Учебник) / Prof. N. V. Makarova, ed. Moscow: Finance and Statistics, 1997. 786 p (in Russian).

2. Classifications Download. Combined Nomenclature, 2006 (CN 2006).

www.eu.int/comm/eurostat/ramon/nomenclatures/ index.cfm?TargetUrl=LST_CLS

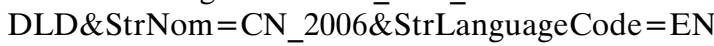

3. CODE UIC 221.

4. Hunt, Ü. J Forecasting of railway freight volume: approach of Estonian railway to arise efficiency. Transport, 2003, Vol 18, No 6, p. 255-258.

5. Hunt, Ü. J. Some methods of calculation of carrying capacity of the railways of the Baltic Region. In: Proc. of Intern. Conf. Ttansbaltica-99, April 1999, Vilnius:
Technika, 1999, p. 392-398 (in Russian with English summary).

6. Hunt, Ü. J. Usage of new tariff model: Approach of Estonian Railway to arise efficiency. In: Proceedings of conference “Transportas-2002”, 8-9 April 2002 (Respublikinès konferencijos „Transportas-2002“, ivykusios Vilniuje $2002 \mathrm{~m}$. balandžio 8-9 d., mokslinių pranešimų rinkinys). Vilnius: Technika, 2002, p. 214-220.

7. Official Journal of the European Communities. Commission communication. code of conduct for the management of the combined nomenclature. CN (2000/ C150/03). 